Ştefan BAGHIU

Faculty of Letters and Arts Lucian Blaga

Sibiu, Romania

stefan.baghiu@ulbsibiu.ro

\title{
TRANSLATIONS OF NOVELS IN THE ROMANIAN CULTURE DURING THE LONG NINETEENTH CENTURY (1794-1914): A QUANTITATIVE PERSPECTIVE
}

Recommended Citation: Baghiu, Ștefan. "Translations of Novels in the Romanian Culture During the Long Nineteenth Century (1794-1914): A Quantitative Perspective". Metacritic Journal for Comparative Studies and Theory 6.2 (2020): https://doi.org/10.24193/mjcst.2020.10.05.

Abstract: This article uses quantitative methods to provide a macro perspective on translations of novels in Romanian culture during the long nineteenth century, by modifying Eric Hobsbawm's 1789-1914 period, and using it as spanning from 1794 (the first registered local publishing of a translated novel) to 1918 (the end of the First World War). The article discusses the predominance of the French novel (almost 70\% of the total of translated novels), the case of four other main competitors in the second line of translations (or the golden circle, as named in the article: German, English, Russian, and Italian), the strange case of the American novel as a transition zone, and the situation of five other groups of novels translated during the period (the atomizing agents: the East European, the Spanish, the Austrian, the Nordic, and the Asian novel). Keywords: Novel, translation, World Literature, quantitative studies, nineteenth century

In this article, I will put forward some data in order to show how translations of novels can be analyzed as cultural phenomena through quantitative methods, focusing on the period in which Romanian literary consciousness was being forged and consolidated: 1794-1918. I have chosen the interval tracing a "long nineteenth century" as a first 
expanded period of novel translation on the Romanian territory and as "a yet unexplored century of literary imports" (Chiorean 153) ${ }^{1}$. I used an index of all the novels translated into Romanian between 1794 and 1989, developed by the Romanian Academy through the Institute of Linguistics and Literary History Sextil Pușcariu, Dicționarul cronologic al romanului tradus în România de la origini până la 1989 [The Chronological Dictionary of the Translated Novel in Romania from its Origins to 1989] in order to delineate the pre-war segment. I borrowed the national novel classifications from the Dictionary (and, in some cases, where a category was missing, I identified it myself), to determine the local translationscape (Smith) of the foreign novel in the age of the World Republic of Letters (Casanova, in her homonymous book). I started off from the idea that the novel is a "first truly planetary literary form" (Moretti, The Novel) which makes itself increasingly known in European culture at the beginning of the nineteenth century and especially at the beginning of the 1830 s (Sassoon, The Culture of the Europeans), later imposing itself as a dominant form of literary exchange and defining the center-periphery relationship in European and global culture. I counted and classified around 2160 stable entries (novels) by their culture of origin, based on the DCRT (1794-1989) (Istrate et al. 2004). I only selected the novels published in volume or feuilleton and eliminated novel fragments mentioned in the DCRT. There are multiple reasons for this: first of all, I considered the feuilleton relevant, since serialized translated novels may represent the more popular publishing fashion for the sensationalist novel, without which the situation of novel translation would be incomplete. Then, I left out the fragments, because it would have been unjust for the fully published novels to be quantified alongside fragments (these are difficult to retrieve anyway, since most of them were divided between magazines or published independently, without being officially registered). Although novel fragments have a significant impact through the game of publicity they create, verifiable even through the

\footnotetext{
${ }^{1}$ In terms of novel translation, the chosen period stretches between 1794 and 1918, from the first novel translation into Romanian published in 1794 (Baltasar Gracián y Morales, El Criticón [The Critic] - this had been translated before by Ioan Baliș in 1754, but had remained in manuscript) to the milestone set by Eric Hobsbawm. Of course, the English Marxist historian proposes 1914 as a concrete milestone, but between 1914 and 1918 the old order gets restructured, with results becoming visible only in 1918. See Eric Hobsbawm, The Age of Revolution 1789-1848 [1962]; The Age of Capital 1848-1875 [1975]; The Age of Empire 1875-1914 [1987].
} 
references included in Romanian novels ${ }^{2}$, they would be better discussed alongside short stories, as the selected fragments were carefully devised to be self-sufficient, functioning outside the original body of the novel (take, for example, "The letter of a father to his son" from Le Lys dans la vallée by Balzac). Undoubtedly, it would be interesting to investigate whether these fragments follow the same model of the French monopoly and to propose an analysis of serialized publishing, but for the time being such a project is difficult to imagine producing any surprises since the DCRT entries mainly confirm the same French monopoly in the case of fragments.

\section{The Critique of Translation and the Novel in the Nineteenth Century: Delineating the Canon}

In terms of local bibliography, a few important studies precede this analysis. Firstly, Paul Cornea's observations in a 1966 article, "Traduceri și traducători în prima jumătate a secolului al XIX-lea" [Translations and Translators in the First Half of the 19th Century] (Cornea, in the volume De la Alecsandrescu), where he discusses the status of intermediaries specifically in this period (generally French translations) and the formation of a modern literary consciousness by means of translation. Thus, it has to be kept in mind that the translations I will be discussing were largely mediated by French versions, at least until the end of the century (1870-1880). The situation persisted in the twentieth century for the commercial canon, especially without actually mentioning the intermediary, as recent studies have shown; for example, this was the case of Dracula, rendered in the 1990s (Martin). However, it must be said from the very start that until recently no quantitative perspective was available on the imports of the modern Romanian literary field. Most studies of this period in terms of translation focused on particular cases connected with linguistic modernization, highlighting in a didactic manner "the enrichment, betterment, and refinement of the Romanian language" 3 due to the programs led by important intellectuals like "Gh. Asachi, I. Heliade Rădulescu and Gh. Barițiu” (Petrea), the relationship between canonical translations and the

2 There is a set of nineteenth century Romanian novels which explicitly mention and build narrative worlds around Le Lys dans la vallée [The Lily of the Valley] by Balzac, although the only fragment in Romanian appeared in 1836, and the whole novel was published as a feuilleton in 1907 and as a complete edition in 1923.

3 “îmbogăţirea, perfecționarea și cizelarea limbii române" (My translation). 
import of certain "universal values" (Pușcaş) etc. It is not difficult to infer that these studies, beyond their analytical importance in the field of linguistics (the relevance of which is faltering anyway, as linguistics moves towards the areas of artificial intelligence and speech processing), simply reiterate commonplace ideas regarding the dynamics of translation, more or less ignoring the necessary mechanisms for understanding these processes. Studies devoted to the history of translation-oriented criticism have proven more useful (Lungu-Badea, "Necesitatea" [The Necessity]; Repertoriul [Repertoire]; Idei [Ideas]; Terian, "Translating the World"), because they question the institutional basis of the phenomenon ("teaching French in some schools, as required by the Organic Regulations, and Western studies carried out by the future literary and cultural elite of Romania"4 as well the issue of "fidelity") (Lungu-Badea, "Necesitatea"), or the "emergence of translation theory" (Terian, "Translating" 19).

To begin with, I will discuss a few aspects highlighted by Terian in his article from The Culture of Translation in Romania (2018), precisely because it tackles the problems that I am most interested in for my analysis. Far from trying to discuss novel translation from a technical or linguistic point of view (an area in which I lack the necessary expertise), I will attempt to trace the critical clichés regarding translation during the nineteenth century and to confront them with the "realities" of the field (considering the quantitative landscape to be closer to the "reality" of production, due to its abstract nature), with a view to determining whether "translations make a literature" and how we can verify with quantitative tools Terian's thesis, according to which in the 1866-1918 interval the Romanian literary field transitioned "from the Western canon to the Literature of the World". Terian describes the response to the "increasingly evident Westernization of Romanian society (...) [and] an unprecedented rise in the number of literary translations into Romanian" as "a series of adverse reactions on the part of the local elites". Also, he quotes Mihail Kogălniceanu's (1817-1891) "Introducțiune" [Introduction] (1840), which "denounces the practice [of translation], arguing that foreign renditions hinder the evolution of Romanian literature" (21), as opposed to Ion Heliade-Rădulescu (1802-1872), who "perceived the practice of translation not as a threat to originality, but a catalyst, the more so when a translator is challenged to render

\footnotetext{
4 "predarea limbii franceze, după cum prevedea Regulamentul organic, în unele școli și studiile făcute în Occident de viitoarea elită literară și culturală a României” (My translation).
} 
the works of prestigious writers" 5 (21). Here, Terian shows that even in the most enthusiastic stage, the elite's perspective on translation is limited to the canon, as George Barițiu (1812-1893), too, "saluted the prospect of «translating all classics, old and new», which would «give strong wings to Romanian literature, allowing it to rise to new heights»" (21). As Maria Chiorean synthesizes the situation, "regardless of their divergent ideological agendas, the most vocal autochtonous critics were all in favour of translations, focusing on great canonical works of Western literature at first" (Chiorean 153). What was truly lacking in terms of the novel in the age of these "battles" for the acceptance of translation was precisely the noncanonical aspect. Until 1846, very few novels were translated into Romanian, the vast majority originally written by authors like Baltasar Gracián (El Criticón [The Critic], rendered in 1794), Jacques-Henri Bernardin de Saint-Pierre (La Chaumière indienne [The Indian Cottage] in 1821 and Paul et Virginie [Paul and Virginia] in 1831), Voltaire (Zadig ou la destinée [Zadig, or the Book of Fate] in 1831), Daniel Defoe (Robinson Crusoe in 1835), Lesage (Le Diable boiteux [The Devil upon Two Sticks] in 1835 and Histoire de Gil Blas de Santillane [The History of Gil Blas of Santillane] in 1837), Rousseau (La Nouvelle Heloïse [The New Heloïse] in 1837), Chateaubriand (Atala and René in 1839), Hugo (Le Dernier jour d'un condamné [The Last Day of a Condemned Man] in 1839), Cervantes (El ingenioso hidalgo Don Quijote de la Mancha [The Ingenious Gentleman Don Quixote of La Mancha] in two volumes in 1840), Goethe (Die Leiden des jungen Werthers [The Sorrows of Young Werther] in 1842) and Eugène Sue (Le Juif errant [The Wandering Jew] in 1844).

Up until 1846, these canonical figures represented the only translated sources in the novelistic field (with very few additions, according to the DCRR) that could have contributed to a discussion surrounding novel production. This canonical state, however, is perfectly explicable in the age of "genius factories"6 (Tudurachi). The first Romanian novel (with the exception of Istoria ieroglifică [The Hieroglyphic History], entitled "romanț" and written in verse at the beginning of the eighteenth century)

5 The "constellation" proposed by Heliade-Rădulescu in this canonical pantheon of translation is especially interesting: "This is one of the main reasons why, in 1846, Heliade-Rădulescu envisioned a comprehensive Universal Library, where he sought to reunite the most emblematic ancient and modern writers, from Homer, Aeschylus, Seneca, Virgil, Dante, Shakespeare, and Cervantes to Voltaire, Goethe, Byron, Balzac, Scott, and Eugène Sue" (Terian, "Translating” 21).

6 "fabrica de geniu" (My translation). 
appears in 1844 (according to the DCRR). This means that upon its emergence (both in local production and through a significant number of translations), the novel bypasses these foundational cultural battles about translation and manifests itself fully through its noncanonical aspect. This is when adventure novels enter the stage (Alexandre Dumas-Père as early as 1846 with Le corricolo [1843]), as well as sentimental novels (George Sand in 1847, with Indiana [1832]). Followed by a series of subgenre novels (or canonical variants of adventure literature, like Gulliver's Travels, rendered in 1848), they began to shape a diverse Romanian literary consciousness visible in local commentaries only in the third part of the nineteenth century, in the same period when Titu Maiorescu (1840-1917) used his position as one of the most important critical voices of the time to stress the importance of the genre (Maiorescu, "Literatura" [Literature] [1882]). Later on, at the turn of the century, "[r]ather than judged aesthetically, translations were measured with this political or, more exactly, nationalist yardstick" (Ursa 313).

\section{Foreign Proportions of Novel Import}

However, to what degree do these quantities expose/show a certain minor condition of Romanian culture in the nineteenth century and what does this condition mean? Moreover, how does it look when compared to other contemporaneous minor/major conditions and, moving towards World System Analysis, what can it tell us about the center-periphery dynamics in the formation of Romanian culture? An extremely useful starting point is the one made by Sean Cotter in Literary Translation and the Idea of a Minor Romania (2014): "the minor is not a failed state or potentially great one, but a translated nation" (2)7. Despite the fact that his analysis has poetry as the main focus, we can witness the same phenomenon in the case of the novel. Following in Cotter's footsteps, I would define a minor literary culture through the relationship established between local production and literary translation. In terms of poetry, the situation has not yet been analyzed (there is no comparative report on translation and autochtonous production in terms of volume publishing or periodicals), but the novel has been investigated from this point of view. According to Andrei Terian's results from "Big

7 Although Cotter's studies refer primarily to the communist period, this introduction based on the figure of the national poet allows for correlations between the concept and the modern literary field. 
Numbers: A Quantitative Analysis of the Development of the Novel in Romania" (2019), at least in the 1860-1918 period (before 1860 the situation can be traced in detail anyway, but the small number of translations $-5-10$ novels rendered and produced per year - makes the quantity irrelevant for statistical research) there was a sharp increase in novel translation starting in 1875 , with three peaks and three points of relative decline, which do not, however, go below the upper limit of autochtonous production (increases in 1882-1893, 1896-1899 and 1903-1912, see Fig.2: The Evolution of the Romanian Novel Between 1860-1917). The translated novel is more present than the autochtonous one (8 times more present, based on a few intuitive calculations in the DCRR and DCRT, as well as Terian's graphs), and, in Terian's view, this proves the "absence of a major rise" (61) and indicates that this is a quantitative issue: "the Romanian novel does not manage to reach the critical mass which would enable it to rise" (61). It comes as no surprise, then, that the end of the nineteenth century and the beginning of the twentieth century brough about "anticolonial" measures, justified in the ideology of traditionalist movements as being counter to the "colonial danger" represented by this dominance of Western translations (Morariu, Anticolonizare 7, Goldiș 101) ${ }^{8}$. As for the translated novel, Terian makes an excellent point arguing that the big numbers are caused by serialized publishing, which represented the most prevalent vehicle for the development of novel translation in 1882-1913:

$[M]$ any Romanian writers still nourished the ambition of being published in volume form and thereby increasing their symbolic capital, the majority of foreign authors probably had no inkling they were going to be published in a regional language, which means that for them the issue of choosing between volume and magazine did not even exist. As for the newspaper owners, they treated novels as mere collections of trivialities and it is therefore not to be wondered that they preferred working with unassuming translators rather than with authors with potential "artistic" pretentions. At any rate, by correlating the respective percentages with the already existing difference in favor of the translated novel, we can better understand why and how the institution of the feuilleton has deepened the gap between the local and the imported novel in Romania (61).

\footnotetext{
8 As shown by Alex Goldiș, "Iorga openly argued for a «cultural protectionism» that, incidentally, went so far as to propose raising the taxes on imported books. As a representative of sămănătorism, a conservative movement that extolled ethnicity, he believed that his initiative would stimulate national creativity."
} 
This explanation is helpful here in two ways. First, it accounts for the prevalence of French literature (more popular and accessible for translation to the feeble Romanian intellectual elite of the time, although the French dominance was countered by extremely influential programs, whether through compensation, dumping, or detour) (Terian, "National Literature"). Second, it explains the proliferation of adventure, sentimental, and mystery novels through the phenomenon of translation (with equivalents in the local novel production - Terian et al., "Genurile" [Genres]; "Genurile 1901-1932" [Genres in 1901-1932]). A culture of translation, then, in an age when the explosion of novel production had been underway for decades in other European national cultures. What do the autochtonous quantities look like?

\begin{tabular}{|l|l|}
\hline Source country/culture & $\begin{array}{l}\text { No. of Novels } \\
(\mathbf{1 7 9 4 - 1 9 1 8})\end{array}$ \\
\hline French & 1473 \\
\hline German & 131 \\
\hline English & 126 \\
\hline Russian & 121 \\
\hline Italian & 107 \\
\hline American (USA) & 70 \\
\hline East European (Hungarian, Serbian, Czech, Polish) ${ }^{9}$ & 43 \\
\hline Spanish & 39 \\
\hline Austrian & 26 \\
\hline Nordic (Danish, Swedish, Iceland and Norwegian) & 16 \\
\hline Asian (Japanese, Korean, and Indian) & 6 \\
\hline TOTAL & $\mathbf{2 1 5 8}$ \\
\hline
\end{tabular}

Although it has been constantly theorized and discussed as a phenomenon of cultural monopoly, the impact of French culture in the nineteenth century on small European and non-European cultures might have been underestimated in literary

9 I added the Greek and Hebrew novels here because of the geographic proximity and locations of authors in this geopolitical context, but the numbers are too insignificant to change any position within the table. 
research. What the table above shows is quite impressive, even if this dominance was largely well-known: in every single way, the Romanian novel of the nineteenth century is radically dependent on the French one. And, accordingly, the landscape of modern novel translation cannot be represented without discussing the situation of French novel translation. Out of the 2158 translated novels published in volume or feuilleton on the Romanian territory, around 1473 are French and only 685 belong to other literatures. In short, in the long nineteenth century, almost $70 \%$ of translated novels are French. I have created a graph to visualize French entries in relation to all the other novels (had I fragmented this category by specific cultures, the results would not have been eloquent, since even the second entry in the table contains a mere 131 novels, i.e., a one and a half novel per year average). I traced the evolution of every novel category (French, English, German etc.) and decided to represent the situation starting in 1835 (when the translation field becomes relatively stable, with at least one rendition every year), thus excluding only eight novels from the graph (indeed, in the first stage of modernity, between 1794 and 1834, eight translated novels were published, most of which have already been mentioned in the previous section and belong to the French, Spanish and English cultures) (Graph 1).

The table shows the division of non-French translations into Romanian on two levels of relevance: 1) the golden circle comprises German, English, Russian, and Italian novels (for the purpose of this study, I will only comment on the evolution of German and Russian translations), which will be called competitors. Not because they stood a chance against French novel translations, but because they fought each other for a place in Romanian culture (a funny way of putting this, of course, since no literature was actually fighting to penetrate Romanian culture at that point in history). The American novel emerges as a newcomer, embraced by local intellectuals even in the more conservative areas (influenced by trends like "sămănătorism" or "poporanism") especially for the sake of its novelty. Somehow (and I will give a more thorough explanation of this), Romanian writers and editors felt that America was a young territory still under development, and viewed it as being equal to Romanian culture at best (no matter how strange it seems today); 2) the atomizers are primarily East European cultures (Hungarian, Czech, Polish, Serbian novels), Nordic (the Danish, Swedish, Islandic, and Norwegian novel), Asian (Japanese, Korean, Indian), alongside 
two literatures that - for some reason, either geographic distance or imperial proximity - never managed to enter the first category: the Spanish novel and the Austrian one.

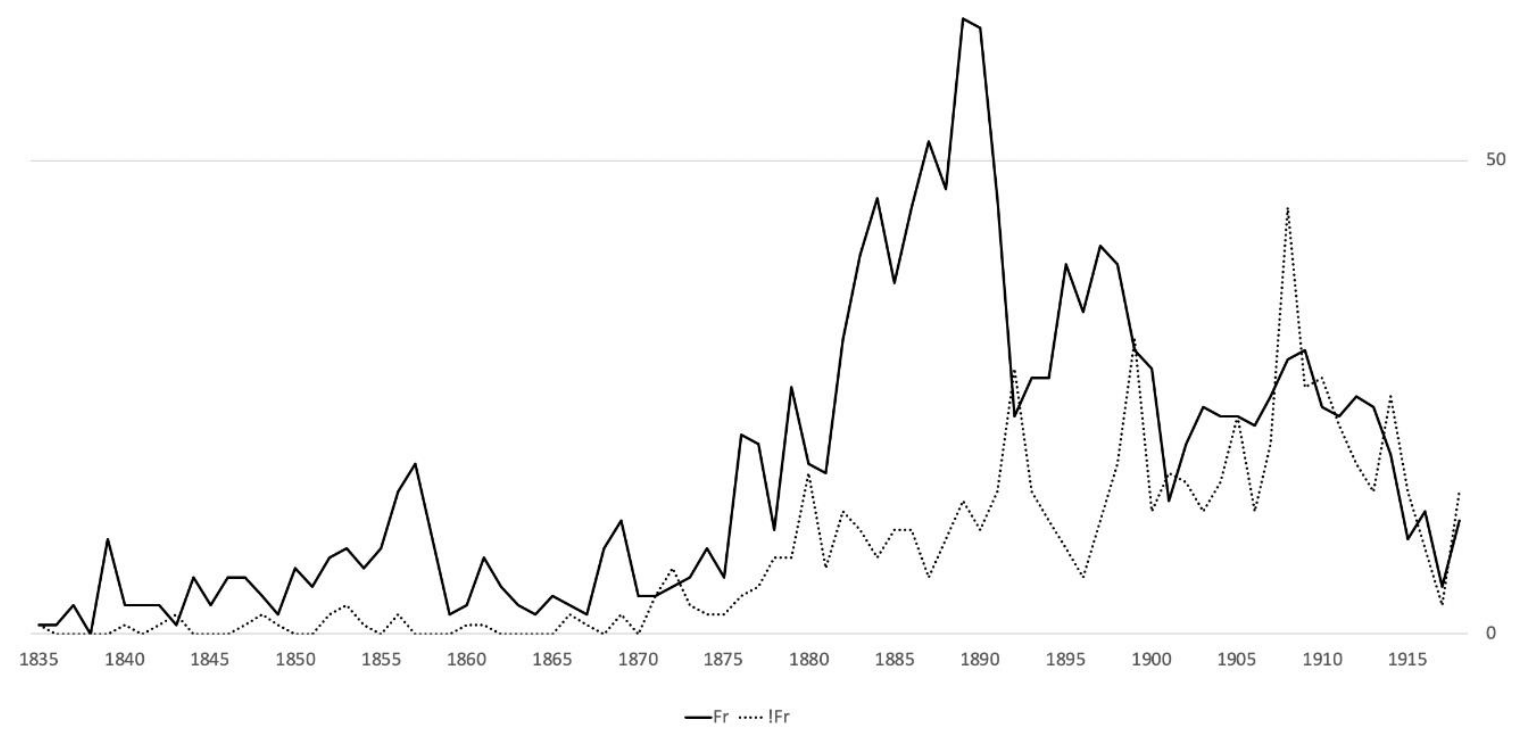

Graph.1: The Dynamics of Translation (1835-1918) between French (Fr) and NonFrench (!Fr) novels

\subsection{The French Novel and Its Dominance}

As shown by the numbers and the evolution of the graph, the French novel constitutes the entire mass of novel translation in the period. Linking this observation to a few recent results obtained through quantitative analysis, which demonstrate that in the autochtonous novel "Paris is the foreign city most frequently used as setting" 10 (Baghiu et al., "Geografia internă" [Internal Geography] 33; Baghiu et al., "Geografia (19011932)"), we can acknowledge the fundamental importance of the capital of the World Republic of Letters (Casanova) on Romanian territory and perhaps elsewhere, as well (Morariu, Affective Geography 128-146). In a section of my previous article, "The French Novel: A Distant Reading of its Renditions in Communist Romania (1944-1989)" (where I pointed out the same aspect, namely the dominance of the French novel among the Western cultures which entered Romanian literature after 1947), I provided more

10 "Parisul este cel mai frecvent întâlnit oraș, străin al desfășurării acțiunii” (My translation). 
details about the precedents of French literary dominance under communism, reviewing a few interesting situations related to the peaks of French novel translation:

during the $19^{\text {th }}$ century, Alexandre Dumas and Victor Hugo have had a great reception in South and Eastern Europe, while Eugene Sue had little reception, at least by the records made available by Franco Moretti in his famous Atlas, which I have confronted to local dictionaries of translated novels. Stendhal and Balzac were notable figures in Central Europe, but not in Eastern Europe (Moretti, Atlas 179).

This is the same significant triad of French authors that gained access to the Romanian cultural space in the period under discussion: Hugo with over 10 novels and reissues $^{11}$, Dumas-Père with more than 65 novels and reissues ${ }^{12}$. Eugène Sue leads alongside them, with 17 entries ${ }^{13}$. But the French literature absorbed into the Romanian field during this time also includes authors like the vicomte d'Arlincourt (Le solitaire is rendered in 1837), Charles-Alphonse Brot, Jean-Pierre Claris de Florian (especially with their historical and adventure prose) and the sentimental novels of Madame de Staël (Corinne ou l'Italie [Corinne, or Italy] in 1846) and George Sand (Le Sécretaire intime [The Private Secretary], rendered in 1847). Although Balzac's case throughout the nineteenth century is an interesting one, it must be said that he only truly enters the space of translation in 1896, at the same time as Alphonse Daudet and Guy de Maupassant and alongside Zola (in 1897). Maupassant's presence is accentuated in 1908 and 1909, when the renditions of Une vie [One Life] and, a year later, Fort comme la mort [Strong as Death] and Pierre et Jean [Pierre and Jean] are completed. As I was saying, despite the fact that Balzac was virtually the continental representative of the novelistic genre, which gains momentum precisely in the 30s, when he was conducting his literary activity, his prose is interestingly represented by a single short fragment in Romanian culture (mentioned in the previous subchapter) until 1852, when La Femme

\footnotetext{
11 (1839; 1862-1864 [six volumes of Les Misérables]); 1874; 1875; 1885; 1888; 1891; 1898; 1908; 1916). 12 (1846; 1846-1848 [3 volumes]; 1847; 1848; 1849 [2 novels]; 1851; 1853 [2 novels]; 1855 [3 novels]; 1856 [4 novels]; 1857 [8 novels]; 1858 [4 novels]; 1860; 1861; 1862; 1864 [2 novels]; 1869; 1871; 1873; 1874; $1877 ; 1878 ; 1880$ [2 novels]; $1881 ; 1883 ; 1884 ; 1885$ [3 volumes]; $1886 ; 1889$ [3 novels, one in 6 volumes]; 1893; 1897; 1898; 1899; 1901; 1902; 1903; 1906; 1907 [3 novels]; 1909; 1911; 1915; 1916; 1918).

13 (1846; 1852; 1853; 1854 [2 novels]; 1857 [2 novels]; 1858 [2 novels, one in 3 volumes]; 1877; 1879; 1884; 1885 [2 novels]; 1889; 1891; 1896).
} 
à trente ans [A Woman of Thirty] is finally translated. Then, a break occurs until a new fragment from Gobseck is rendered in 1870 (the whole text is published in feuilleton in 1908 and in volume in 1911). Nonetheless, most of his important works are published after 1896, starting with Eugénie Grandet. The essential point is that, in terms of translation into Romanian, Balzac is a cultural product of the early twentieth century (especially after 1908, his literature is constantly reedited) ${ }^{14}$. These are a few of the curiosities registered in translation (the French novel in the long nineteenth century deserves a separate article, of course, to discover the ideological tendencies determining translation programs and the disparities which might facilitate the understanding of the autochtonous translation dynamics). Moreover, the greater the mass of translations from a certain culture (1470 French novels), the harder it is to trace its evolution within the Romanian field (finding a theoretical incentive is difficult without conducting supplementary quantitative and distant reading research). But what is the situation of the other translated novels?

\subsection{The Competitors: the German Novel, the Russian Novel, and the Political Case of the American Novel}

In order to observe the translation dynamics for other important literatures which enter the Romanian field in the nineteenth century and up until 1918, we must trace the roots of these developments. There is not enough space here for an exhaustive account, so I will only discuss three literatures (keeping in mind the intention to address the English novel and the Italian one on another occasion) which become visible in the Romanian space through translation and generate (as far as I can infer at the moment) three different entry types. I will expand upon the intention of translation as it appears retrospectively. I am not necessarily pointing towards a sort of collective subconsciousness of the small Romanian literary field, but I am interested in the successive pleas of certain groups for specific national literatures, which produce three different configurations: A) the German novel, born out of an academic interest, especially in the high-culture or intellectualized forms of certain novelistic genres and subgenres; B) the Russian novel, filtered through the canon, with the big names of the

14 (1852; 1891; 1892; 1894; 1896; 1897; 1898; 1908 [2 novels]; 1910 [2 novels]; 1911 [2 novels]; 1912; 1913 [2 novels]; 1914 [2 novels]; 1916 [3 novels]; 1917). 
translated authors leaving very little room for any negotiation with subgenre literature; C) the American novel - whose adoption was motivated by structural empathy and political motives.

2.2.1. With the German novel, it is noticeable that it enters the Romanian field as already canonized, forcefully, through Die Leiden des jungen Werthers [The Sorrows of Young Werther] (rendered in 1842). The absorption of German literature into the Romanian sphere is directly connected to an academic interest, a profile which will be later consecrated in the programs of the Junimea [The Youth] society and through its efforts to consolidate a better relationship with German culture in order to counter the French dominance (Terian, "National"; "Mihai Eminescu"). Here, the mass tends to imitate the canon. No matter the genre or subgenre of the novel, only highbrow or academic novels are translated in this period. German literature enters the sphere of translation especially after 1872 (until then, the rendered titles can be counted on one hand) through rewritings of lowbrow fiction, thus making adventure and sentimental novels more intellectual (Edmond Hahn, Heinrich J. Kampe, Friedrich Gerstäcker including fragments from his intellectual sensationalist novels such as The Novelist; likewise, the translated works of Heinrich J. Kampe caught the attention of Titu Maiorescu), through moralizing writings (novels like Eufrosina sau Virtutea unei femei [Eufrosina or a Woman's Virtue], whose author remains unknown and which was rendered in 1875 or Die Bettlerin vom Pont des Arts [The Beggar Girl of Pont des Arts] by Wilhelm Hauff) or, more often, through historical novels (by Paul Grimm, Georg von Brühl or Georg F. Born) - in spite of being presented as "sensation novels", they remain rather academic; for the post-1900 period, we could also mention Varlam Forst, Fritz Oswald Bilse and Paul Heyse, or even the novels entitled Plevna (alongside figures like Friedrich Schiller).

2.2.2. In the case of Russian novels, it is clear that due to the canonical writers being translated, the literature of the Tsarist Empire that permeates Romanian culture has the most coherent configuration in terms of value. Here, the mass is the canon. Therefore, because it does not suffer the pressure of academic interest, nor is translation intensive enough to grant it an increased heterogeneity, the category of Russian literature 
corresponds to an acute canonical interest in this period. After the first translations from Taddei Bulgari (historical and social novels), the process continues with Gogol, Lermontov, Turgenev, and Pushkin until 1883, when these exclusively canonical renditions reach the summit with Gogol's Taras Bulba (also referenced in the most important encyclopedic literary experiment of the time, the 1874 Pseudo-Kynegetikos by Alexandru Odobescu [1834-1895]). The first translation of a text by Dostoevsky appears in 1886 - The Insulted and the Injured in feuilleton, with Crime and Punishment being serialized in 1888 (published in volume in 1898 by the Socec publishing house). Up until 1898, when Alexei Tolstoy's The Tsar's Cruelties. Mysteries from the Life of Ivan the Terrible is translated and published, all Russian novels that enter Romanian culture, therefore, represent the strongest canonical constellation of all the translated literatures, in the sense that they are not subjected to the company of sensationalist novels or lowbrow literature. Even in the few cases where genre literature is translated, it is generally filtered through an intellectual lens, just like with German novels (the works of Bulgari, Vsevolod Garsin or Rusin Piotrowski, authors of historical novels). Nikolai Gavrilovich Chernyshevsky's What Is to Be Done? is rendered in 1894, and in the 1900 s it will begin to be discussed as a political novel (in articles entitled, for example, "Un roman al Rusiei revoluționare" [A Novel of Revolutionary Russia]). Leo Tolstoy also enters the stage in 1899 with The Resurrection, translated and published in feuilleton. But before any important translation could follow this feuilleton, Maxim Gorky's My Fellow-Traveler appears in the Romanian literary field as one of the most discussed and present works of Russian literature at the beginning of the twentieth century (a high number of articles are indexed in the DCRT as early as 1901). It is followed by Vladimir Korolenko's 1905 The Blind Musician and, in the same year, by Olga Leontiev's Tragedy of the Grand Duke Sergei and A. I Kuprin's A Small Russian Garrison (the signs of a much-awaited atomization of the canon, which, since the first translation of a Russian novel and until 1905, had incorporated names like Matmoff Pinevici, I. N. Potapenko or L. N. Andreev; all the while, the consistent translation of Dostoyevsky, Lermontov, Tolstoy and Gogol was continuing). On this background, already shaped by a partial canonical relaxation, a canonical mutation occurs when Gorky's Mother is translated, alongside Tolstoy's 1910 The Resurrection, culminating with the two volumes of War and Peace (1911) (in the same year as 
Dostoyevsky's The House of the Dead and a year before the 1912 translation of Turgenev's Fathers and Sons - which had been present in literary commentaries since 1883, launching an invitation that would remain unanswered for thirty years). The last years of the period bring about the canonical consolidation of translated Russian literature, through Dostoyevsky (The Brothers Karamazov in 1915), Dimitri Sergheevici Merejkovski (The Gods are Dead. The Novel of Julian the Apostate in 1916) and Gorky (My Childhood in 1918) (alongside Kuprin's Small Russian Garrison and Turgenev's Smoke in 1915).

2.2.3. As I will try to demonstrate in this subchapter, the local interest in the American novel is more difficult to decode, because it actually derives from a political interest, which was generally ignored in literary criticism. The thesis is also formulated by Rodica Mihăilă, who shows that "in the case of American literature, the politics of Romanian translations was dictated first and foremost by political motives” (Mihăilă 286). Although the American novels translated into Romanian are close to the competitors' golden circle, they are not all that relevant to Romanian culture until very late (foreseeing the results of another research project still underway, I can argue that it becomes truly relevant in the proximity of World War II). This is because the American novel is largely represented by adventure or travel literature and by sensationalist fiction, "translated from German for popular consumption" (Mihăilă 286). Here, the canon imitates the mass. Therefore, even in 1933 (77 years after the publishing of the first translated American novel), the historian Nicolae Iorga (1871-1940) deemed it necessary to offer clarifications when discussing the situation of American art: "unfortunately, there are still people who believe that America has no art or literature of its own, which is a huge mistake"15 (Iorga 242). Moreover, Iorga uncovers an entire toolbox of possible empathy for the Americans, based on the plight of the brutally colonized American Indians: "specifically because they are being defeated and destroyed, we - who have often been defeated on these lands, and whom so many tried to destroy and banish from these lands, but have never succeeded and never will - must have sympathy for the Indians" (Iorga 249). The connection is not arbitrary: even in the

15 “[s]unt și acum, din nenorocire, persoane care cred că America n-are o artă și o literatură a ei, ceea ce este o foarte mare greșeală” (My translation). 
preface to the first American novel rendered in Romanian, Uncle Tom's Cabin (translated as "Coliba lui moşu Toma sau viaţa negrilor în sudul Statelor Unite din America" [Uncle Tom's Cabin, or the Life of Black People in the Southern States of America], with a reference to slavery in M. Kogălniceanu's [1817-1891] preface), the political agenda was already visible, and the novel was to be directly used for the liberation of Roma people. Although the novel had been translated almost instantly in all European countries (Kohn) and in Russia and although it can be associated with the sentimental novel, studies have shown that the genre has been important in conveying political attitudes:

During a century that ran from Richardson's Pamela (1740) to Harriet Beecher Stowe's Uncle Tom's Cabin (1852) sentimental novels were in the vanguard of formulating the notion of an affectively charged association among distanced readers. Sentimental discourse and its imagined communities, moreover, extended beyond the novel to figure prominently in political, moral, and aesthetic theory (...) (Cohen 106).

Rodica Mihăilă also mentions the translations from Edward Bellamy's Looking Backward (translated in 1891). However, it is only by the end of the period that the truly social signals appear, through the translation of Upton Sinclair, who will be read alongside the social (and often socialist) literature translated in Romania during the interwar period.

\subsection{The Atomization: the Neighboring Literatures, the Nordic Novel, the Asian Novel}

The most important atomizations of the dominant literary units in translation (the French, German, English, Italian novel etc.) occur by means of two complementary compensation mechanisms, together forming a real process of cultural dumping (Terian, "National"): the first is the encounter and familiarization with neighboring, East European and Nordic literatures as a form of self-recognition in other peripheral narratives (Borza, "Translating"); the second is the attempt to compensate for the absence of a colonizing dimension by exoticizing certain spaces, visible in the important travel writings of the time or in certain Romanian novels (Baghiu et al., "Geografia 1901- 
1932”). This, as well as the fact that the first powerful translations from Asia, Africa or Latin America appear only in 1948 (Baghiu, "Translating Hemispheres") are the reasons why I intend to analyze the issue in a separate study.

\section{Conclusions}

For now, however, this is where we find ourselves: 11 important source areas can be found in this exhaustive statistic of novel translation, including only 20 national literatures. This is all that actually enters our "translated culture" during the long nineteenth century. $70 \%$ of these translations are represented by French literature. The remaining $30 \%$ is in its turn divided between $90 \%$ continental literature coming from the center and 10\% continental literature from the periphery. Only 6 novels from outside Europe, United States and Russia are rendered, and their translation involves an intensive process of exoticization which doubles the condescending Orientalist discourse of the contemporaneous diaries, novels, and travelogues. This shows that, while a "minor culture/literature" is, of course, a "translated culture", it is not at the same time interested in translating the planet. This is what the long nineteenth century has to offer: big numbers of novel translations that vary, yet too little.

ACKNOWLEDGEMENT: This work was supported by a grant of the Romanian Ministry of Research and Innovation, CNCS - UEFISCDI, project number PN-III-P1-1.1PD-2019-0946, within PNCDI III. (TRANOV: http://grants.ulbsibiu.ro/tranov/).

\section{References:}

Baghiu, Ștefan et al. "Geografia romanului românesc (1901-1932): Străinătatea” [The Geography of the Romanian Novel (1901-1932): Spaces from Abroad]. Transilvania, 10, 2020: 1-11.

Baghiu, Ștefan et al. "Geografia internă a romanului românesc în secolul al XIX-lea" [The Internal Geography of the Romanian Novel in the 19th Century]. Transilvania, no. 10, 2019: 29-43.

Baghiu, Ștefan. "The French Novel in Translation: A Distant Reading for Romania During Communism (1944-1989).” Transylvanian Review, XXVIII, Supplement no. 1, 2019: 83-100. 
---. "Translating Hemispheres: Eastern Europe and the Global South Connection through Translationscapes of Poverty." Comparative Literature Studies 56, no.3, 2019: 487-503.

Borza, Cosmin. "Translating Against Colonization. Romanian Populists' Plea for Peripheral Literatures (1890-1916)". The Culture of Translation in Romania, 2018: 31-45.

Casanova, Pascale. The World Republic of Letters. Harvard University Press, 2004.

Chiorean, Maria. "Maria SASS, Ștefan BAGHIU, Vlad POJOGA (eds.), The Culture of Translation in Romania, Peter Lang, 2018, ISBN 978-3-631-76642-2 (Print), 326 p." Metacritic Journal for Comparative Studies and Theory, 2, 2019: 152-158.

Cohen, Margaret. The Literary Channel. The Inter-National invention of the Novel. Translation Transnation, 2001.

Cornea, Paul. De la Alecsandrescu la Eminescu. Editura Pentru Literatură, 1966.

---. Oamenii începutului de drum. Cartea Românească, 1974.

Cotter, Sean. Literary Translation and the Idea of a Minor Romania. Rochester: Boydell \& Brewer, University of Rochester Press, 2014.

Istrate, Ion, editor. Dicționarul cronologic al romanului tradus în România de la origini până la 1989. Bucharest, Editura Academiei Române, 2005.

Goldiş, Alex. "Beyond Nation Building: Literary History as Transnational Geolocation." Romanian Literature as World Literature, edited by Mircea Martin, Christian Moraru, and Andrei Terian, Bloomsbury, New York, 2018: 95-115.

Hobsbawm, Eric. The Age of Revolution 1789-1848.1962. Orion, 2010.

---. The Age of Capital 1848-1875 .1975. Orion, 2010.

---. The Age of Empire 1875-1914 .1987. Orion, 2010.

Iorga, Nicolae. "Privire asupra literaturii americane." Conference paper from Bucharest, April 1930. Published in Nicolae Iorga. America şi Românii din America - Note de drum şi conferinţe. Vălenii-de-Munte, 1930: 242-271.

Kohn, Denise et a. (Eds). Transatlantic Stowe. Harriet Beecher Stowe and European Culture. University of Iowa Press, 2006.

Lungu-Badea, Georgiana. "Necesitatea unei critici a traducerii." Analele Universității de Vest din Timișoara. Seria Științe Filologice. XXXVI-XXXVII, 1998-1999: 199-222. ---. Idei și metaidei traductive românești. Secolele XVI-XXI. Eurostampa, 2013. 
---. Repertoriul traducerilor românești din limbile franceză, italiană, spaniolă (secolele al XVIII-lea și al XIX-lea). Editura Universității de Vest, 2006.

Maiorescu, Titu. "Literatura română şi străinătatea” [1882]. In Titu Maiorescu, Opere, vol. 1, Edited by D. Vatamaniuc, Foreword by Eugen Simion, Univers Enciclopedic, 2005 .

Martin, Anca-Simina. "Romanul Dracula în limba română: ipoteza intermedierii prin traducerea franceză.” Transilvania, 4,2020: 38-43.

Mihăilă, Rodica. "The Politics of Translation: The American Novel in the 19th Century Romanian Territory.” English American Studies XI, Editura Universităţii de Vest,2005: 285-291.

Morariu, David. “Anticolonizare și autocolonizare: relație cauză-efect. Cazul traducerilor." Transilvania, 2 ,2019: 4-10.

Morariu, David. "The Affective Geography of Paris in the $19^{\text {th }}$ Century Romanian Novel: Between Admiration and Aversion”. Metacritic Journal for Comparative Studies and Theory, 6.2, 2020: 128-146.

Moretti, Franco. Atlas of the European Novel 180o-190o. Verso, 1998.

Moretti, Franco (ed.). The Novel, volume 1: History, Geography, and Culture. Princeton University Press, 2006.

Petrea, Elena. "Traducerile din opera lui Victor Hugo ca vehicul al modernizării limbii române literare în prima jumătate a secolului al XIX-lea.” Studii de Ştiinţă și Cultură 5, no.16,2009: 96-103.

Pușcaş, Diana Lora. "Traduceri importante ale secolului al XIX-lea în literatura română.” Annales Universitatis Apulensis. Series Philologica 18, no.3, 2017: 9398.

Sassoon, Donald. The Culture of the Europeans. From 1800 to the Present. Harper Collins, 2011.

Smith, Jordan A. Y. "Translationscapes: On the Legibility of Transnational Ideologies in World Literary Systems." Comparative Literature Studies 54, no. 4, 2017: 749770.

Terian, Andrei et al. "Genurile romanului românesc în secolul al XIX-lea. O analiză cantitativă.” Transilvania, no. 10, 2019: 17-28. 
Terian, Andrei et al. "Genurile romanului românesc (1901-1932)" [Genres of the Romanian Novel (1901-1932)]. Transilvania, no. 10,2020: 53-63.

Terian, Andrei. "Big Numbers: A Quantitative Analysis of the Development of the Novel in Romania." Transylvanian Review, vol. XXVIII, Supplement no. 1,2019: 55-71.

---. "Mihai Eminescu. From National Mythology to the World Pantheon." Romanian Literature as World Literature, edited by Mircea Martin, Christian Moraru, Andrei Terian, New-York-London-Oxford-New Delhi-Sydney, Bloomsbury Academic, 2018: 35-54.

---. "National Literature, World Literatures, and Universality in Romanian Cultural Criticism 1867-1947." CLCWeb: Comparative Literature and Culture 15, 5,2013, http://docs.lib.purdue.edu/clcweb/vol15/iss5/11.

---. "Translating the World, Building the Nation: Microtheories of Translation in Romanian Cultural Criticism." The Culture of Translation in Romania, edited by Maria Sass, Ștefan Baghiu, and Vlad Pojoga, Peter Lang, 2018: 19-29.

Tudurachi, Adrian. Fabrica de geniu. Naşterea unei mitologii a productivităţii literare în cultura română (1825-1875). Institutul European, 2016.

Ursa, Mihaela. "Made in Translation: A National Poetics for the Transnational World." Romanian Literature as World Literature, edited by Mircea Martin, Christian Moraru, and Andrei Terian, New York, Bloomsbury, 2018: 309-325.

Tihanov, Galin. The Birth and Death of Literary Theory: Regimes of Relevance in Russia and Beyond. Stanford University Press, 2019. 